\title{
ŚLĄSKIE NAZWY GEOGRAFICZNE MOTYWOWANE NAZWAMI KOLORÓW
}

Słow a tematyczne: nazwy geograficzne, nazwy kolorów, Śląsk

\section{PRZEDMIOT I CEL BADAŃ}

Kolory uznawane są za podstawowe środki orientacji człowieka w świecie. Są również ważnym elementem konceptualizacji świata. Mogą być wyrazem tożsamości jednostkowej i zbiorowej (Jurek, 2011, s. 71-73), informować o wartościach wyznawanych przez dane społeczeństwo oraz odzwierciedlać sposób postrzegania otaczającej rzeczywistości (Czachorowska, Stypa, 2010, s. 47; Gonigroszek, 2008). Nazwy kolorów są przedmiotem zainteresowania wielu nauk: od fizyki, przez neurologię, psychologię, sztukę, kulturoznawstwo, aż po językoznawstwo, szczególnie semantykę, dialektologię i etnolingwistykę (por. Libera, 1987; Tokarski, 1995; Wierzbicka, 1999; Zaręba, 1954). Nieliczne są prace onomastyczne podejmujące ten temat, por. artykuły o przymiotnikach właściwościowych w hydronimii autorstwa Ewy Jakus-Borkowej (1989) i Jerzego Dumy (2003), Izabeli Różyckiej w mikrotoponimii (2001) czy Iryny Gaponenko w toponimii rosyjskiej, polskiej i białoruskiej (2019).

W swoich pracach na temat onimicznego obrazu Śląska przedmiotem zainteresowania uczyniłam również polskie i niemieckie nazwy geograficzne z elementem nazywającym kolor. Śląsk jest regionem, w którym nastąpiło spontaniczne przejmowanie nazw, będące wynikiem wielowiekowego współżycia różnych grup językowych i etnicznych. Historia Śląska i naturalna symbioza językowo-kulturowa pozwalają traktować na równi nazwy niemieckie i polskie, tym bardziej że nie zawsze można potwierdzić, która $\mathrm{z}$ nazw jest pierwotna. Równocześnie po II wojnie światowej nastąpiły sztuczne, urzędowe zmiany nazw geograficznych. Komisja Ustalania Nazw Miejscowości ${ }^{1}$ miała za zadanie spolonizowanie

${ }^{1}$ W 1948 roku nazwę zmieniono na Komisja Ustalania Nazw Miejscowości i Obiektów Fizjograficznych. 
nazw niemieckich, uwzględniając nazwy istniejące w obiegu potocznym (jak np. na Górnym Śląsku), chociaż nie wszędzie było to możliwe (na Dolnym Śląsku ludność niemiecką wysiedlono). W zaleceniach Komisja miała brać pod uwagę krajobraz i ukształtowanie terenu, a także miejscowe zwyczaje i obrzędy. W swej pracy kierowała się zapisami historycznymi nazw polskich i uwzględniała słowiańskie nazwy osad zaginionych, często nadawała jednak obiektom o nazwach pierwotnie niemieckich nowe nazwy polskie, były to tzw. chrzty, niekiedy nienawiązujące do poprzednich znaczeń (Choroś, 2011, s. 29-31).

W prowadzonych badaniach wykorzystuję metodologię językowego obrazu świata (JOŚ), która zakłada, że elementy języka są nośnikami wiedzy potocznej, wiedzy o sposobach postrzegania rzeczywistości, konceptualizacji świata i wyznawanych wartościach. Takimi elementami języka są (podobnie jak frazeologizmy) nazwy własne. Chociaż same nie mają znaczenia leksykalnego, żywo odczuwany jest ich związek z apelatywnym budulcem, od którego pochodzą. Interesują mnie nazwy odapelatywne, zarówno obiektów zamieszkanych (ojkonimy), jak i niezamieszkanych (anojkonimy), a także oronimy i hydronimy. Nazwy są wyekscerpowane ze „Słownika etymologicznego nazw geograficznych Śląska” (NGŚ) (Rospond $1970 \mathrm{i}$ in.) ${ }^{2}$. W celu uwypuklenia pewnych zjawisk oraz wskazania konotacji i asocjacji oprócz nazw najstarszych (polskich i niemieckich) biorę też pod uwagę nowe nazwy polskie, używane współcześnie. Analiza ma charakter jakościowy, dlatego niektóre powtarzające się nazwy zostały opuszczone.

Niniejszy artykuł jest kontynuacją badań opublikowanych w „Pracach Językoznawczych"3, w części pierwszej opisałam nazwy zawierające przymiotniki czarny, zielony i biały. Pokazałam podstawowe kolokacje, które potwierdziły prototypowe wzorce bieli, zieleni i czerni, ale wprowadziły też nowe, niezapisane w słownikach znaczenia konotacyjne. Korzystając z badań semantycznych i dialektologicznych, przedstawiłam podstawowe opozycje: biały — czarny i zielony — czarny, plasujące się na osi wartościowania dobry — zły, jasny — ciemny, życie - śmierć. Nie wyczerpało to jednak palety barw, które charakteryzują Śląsk. Oprócz kolorów podstawowych, jak rot/czerwony (też rudy) na uwagę zasługują barwy pochodne, których nazwy zostały utworzone od nazw minerałów, metali,

${ }^{2}$ W niektórych przykładach materiał ten został zweryfikowany i uzupełniony, m.in. o dane zawarte w „Elektronicznym słowniku hydronimów Polski” (ESHP). Jeśli to możliwe, w swoich rozważaniach wychodzę od nazw pierwotnych i pokazuję ich odpowiedniki w drugim języku. Ponieważ interesuje mnie przede wszystkim semantyczny aspekt apelatywnego budulca nazw, datowanie jest tu sprawą drugorzędną, np. dla niemieckich nazw ekscerpowanych z powojennych „Monitorów Polskich” i kartoteki URM (eksploracji terenowej z ramienia Komisji Ustalania Nazw Miejscowych i Obiektów Fizjograficznych przy Urzędzie Rady Ministrów) przyjmuję orientacyjne datowanie przed 1945 rokiem.

${ }^{3}$ Tu też omówiłam problematykę kolorów i barw w różnych dziedzinach nauki, a także konotacje, symbolikę i ludową wizję świata zawarte w tych nazwach (por. Lech-Kirstein, 2021). 
kamieni lub substancji barwnych, jak gold(en)/złoty, silber(n)/srebrny, kupfer $(n) /$ miedziany ${ }^{4}$, a także okazjonalne (raczej polskiego pochodzenia): purpurowy, lazurowy, szary, siwy czy szady.

Nazwy kolorów użyte w tytule rozumiem szeroko jako wszystkie elementy nazywające kolor, pochodzące od nazwy koloru czy uruchamiające asocjacje z nazwą koloru. Nie będą to tylko przymiotniki właściwościowe (por. Jakus-Borkowa, 1989, s. 141), jakościowe, tworzące nazwy topograficzne charakteryzujące i kulturowe (por. Myszka, 2006, s. 169), lecz także derywaty, które pochodzą od nazw kolorów. Będą to również nazwy pośrednio nazywające kolor, a bezpośrednio związane $\mathrm{z}$ występowaniem na tym terenie złóż metali i minerałów (np. Złoty Stok, Srebrna Góra). Wszystkie je będę omawiać wspólnie jako te, które dzisiaj kojarzą się z nazwą koloru i tak mogą być postrzegane przez współczesnego użytkownika języka. To, co w momencie nadania nazwy było podstawową motywacją, z czasem mogło stać się mniej przejrzyste, a nawet wyparte przez inne konotacje ${ }^{5}$.

\section{ANALIZA NAZW POCHODZACCYCH OD NAZW KOLORÓW}

\subsection{Niem. gold, golden / pol. złoty}

Przymiotnik złoty wiąże się z wydobywaniem i płukaniem złota na tym terenie, stąd nie zawsze bezpośrednio będzie nazywać kolor. Występowanie tzw. piasków złotonośnych było udokumentowane na Dolnym Śląsku od starożytności. Złoża rud arsenu zawierających złoto ciągną się pasem o długości około $55 \mathrm{~km}$ od Wądroża Wielkiego i Mikołajowic na wschodzie przez Złotoryję do Lwówka Śląskiego na zachodzie. Na południu złoto spotykane było w bloku karkonosko-izerskim. Eksploatacja tego kruszcu z piasków i żwirów odbywała się także w okolicach Strzegomia i Świdnicy, w Górach Sowich, regionie kłodzkim i Sudetach Wschodnich, a także w rejonie Głuchołaz (Grodzicki, 2002, s. 50). Większość nazw geograficznych zawierających przymiotnik złoty występuje właśnie w Sudetach w województwie dolnośląskim.

Symbolika złota w kulturze ludowej i chrześcijańskiej zyskuje przeważnie walor dodatni, związany ze światłem, jasnością, niebem i ogniem (Libera, 1987, s. 126-127). Prototypowe odniesienia koloru złotego do słońca pozwalają umieścić go w podstawowych opozycjach ciepły — zimny, jasny — ciemny

\footnotetext{
${ }^{4}$ Według badań nazwy pochodne od minerałów, metali, kamieni plasują się na drugim miejscu zaraz po nazwach pochodzących od roślin (Madeja, 2010, s. 198).

${ }_{5}^{5}$ Analiza nie obejmuje nazw motywowanych przez inne nazwy własne (nazwy geograficzne i osobowe) typu Srebrne Siodetko (: n. ter. Srebrne Turniczki), Srebrna Dolina (: n. m. Srebrna Góra), Goldberger Vorwerke (: n. m. Godberg, pol. Złotoryja), Slotaglowa (: n. os. Złota Gtowa).
} 
w pozytywnie wartościowanych członach (Tokarski, 2004, s. 103). Pozytywne waloryzowanie wiąże także złoto z górą, a dalej z bogactwem, pięknem i boskością (Libera, 1987, s. 127).

Niewiele śląskich nazw z przymiotnikiem złoty jest tłumaczeniem niemieckiego przymiotnika golden. Większość nazw niemieckich zawiera rzeczownik Gold oznaczający 'złoto jako surowiec', używany w funkcji przymiotnika w znaczeniu, które można znaleźć w słowniku Grimmów: ‘związany ze złotem’, ‘mający kolor złota'. Znaczenia Gold w takiej funkcji w niemieckim to m.in.: 'lśniący, jasny, błyszczący wygląd złota, często w porównaniach', 'złoto jako barwnik', 'w porównaniach dotyczących wyglądu złota' (DWB).

„Słownik staropolski” podaje następujące znaczenia leksemu złoty: ‘zrobiony ze złota, dotyczący złota’, ‘zawierający złoto’ i ‘złotej barwy, złocisty’ (SStp XI 408-409), ,Słownik wileński” powtarza te znaczenia: 'ze złota, od złota’, a także 'podobny do koloru złota, cytrynowo-żółty, wpadający w pomarańczowy' (SWil II 2225) ${ }^{6}$.

W złożonych nazwach geograficznych Śląska człon określany związany jest z górą, stokiem lub żyłą złota: Gold-Berg, dziś Złota Góra 1886, góra, Brama Krzeszowska, Sudety Środ., NGŚ XVI 155; Gold Berge przed 1945, pol. Złocień, wzgórze, pow. żar. i żag., NGŚ XVI 154; Sloto gora ok. 1934, n. ter. w Nowej Wsi Królewskiej, dziś cz. mta Opole, opol., NGŚ XVI 155; Goldberg, też Złotnik przed 1945, wzgórze, daw. pow. woł., NGŚ XVI 157; Gold Höhe przed 1945: niem. 'złote wzgórze', pol. Michałówka, wzgórze, daw. pow. wałb., NGŚ VII, 129.

Nazwy wodne z niemieckim członem gold- wskazują na strumienie i potoki, w których płukano złoto, np. Gold Wasser 1816, pol. Złote Wody, cz. Bartnicy, gm. Nowa Ruda, dlnśl., NGŚ XVI 156; Gold-Wasser 1925, pol. Złotniczka, potok, 1. dopł. Czarnego Potoku, dorz. Bobru, Odra, NGŚ XVI 156, ESHP; Goldbach 1670, pol. Złoty Potok, wś, gm. Leśna, dlnśl., NGŚ XVI 160; Goldbach 1520, pol. Złotno, wś, gm. Szczytna, dlnśl., NGŚ XVI 158; Gold B.[ach] 1830, dziś Złota, struga, 1. dopł. Czernej Wielkiej, Bóbr, Odra, NGŚ XVI 155, ESHP; Goldener B.[ach] 1905, pol. Złotnica, rzeka, 1. dopł. Bystrzycy, dorz. Odry, NGŚ XVI 156, ESHP; Gold Graben, też Schloss Graben 1951, pol. Złotnik, rzeka, p. dopł. Cienkówki, dorz. Oławy, Odra, NGŚ XVI 157; Goldfloß, pol. Złotnik ok. 1911, potok, p. dopł. Mielnicy, dorz. Izery, Łaba, NGŚ XVI 157, ESHP; Gold-Br.[unnen] 1938: niem. Gold Brunnen 'złote źródło', pol. Srebrnik, źródło w Masywie Raduni, dlnśl., NGŚ XIII 13, ESHP.

Człon związany z kolorem złotym łączy się też z innymi określeniami topograficznymi: Goldwiese 1845: niem. 'złota łąka', pol. Złocieniec, os. koło Bartnicy,

${ }^{6}$ Jak podaje A. Zaręba (1954, s. 33), przymiotnika złoty w znaczeniu koloru nie używano w gwarach polskich, chociaż kartoteka SGŚ dysponuje pojedynczymi poświadczeniami. 
gm. Nowa Ruda, dlnśl., NGŚ XVI 154; An der Lunze, an der goldnen Lunze 1845: niem. 'złota łąka', pol. Łacza, rzeka, p. dopł. Młyńska, dorz. Zimnej Wody, Odra, NGŚ VII, 55; Goldene Wald 1785, pol. Złoty Las, os. leśna, gm. Świdnica, dlnśl., NGŚ XVI 159; Goldene Aussicht przed 1945: niem. 'złoty widok', pol. Koło Zakrętu, pole, daw. pow. lwów., NGŚ V, $56^{7}$.

\subsection{Niem. silber / pol. srebrny}

Kolor srebrny w nazwach ma związek $\mathrm{z}$ istnieniem srebronośnych rud ołowiu w rejonie nizinnym Bytomia i Tarnowskich Gór. Pierwsze wzmianki o ich istnieniu pochodzą z XII i XIII wieku (Mikoś, 2002, s. 88-91; Zalewski, 2018, s. 19).

Niemiecki rzeczownik Silber oznacza 'srebro, biały, błyszczący metal, który ze względu na ognioodporność uważany jest za najszlachetniejszy po złocie', w znaczeniach przenośnych oznacza kolor srebrnobiały, odnoszący się do srebrnego obłoku, srebrnego strumyka, srebrnego źródła, srebrnego połysku itp.' (DWB). W nazwach śląskich raczej nie pojawia się niemiecki przymiotnik silbern 'srebrny', ale element silber- - wykorzystywany w apelatywach typu Silberbär, Silbergeld thumaczony jest przez KUNM jako srebrny.

Przymiotnik srebrny (w odmianach fonetycznych siebrny, strzebrny, śrebny, śrebrny, śrzebny, śrzebrny, śrzebrzny) od staropolszczyzny oznaczał 'zrobiony ze srebra, dotyczący srebra' (SPJS), w „Słowniku wileńskim” widzimy znaczenie 'ze srebra', ale także 'mający blask srebra, srebrzysty' (SWil II 1552), dopiero jednak „Słownik warszawski” podaje 'z barwy podobny do srebra' (SW VI 371), a Doroszewski - 'mający kolor srebra' (SJPDor VIII 665).

Semantycznie nazwa koloru srebrnego ma związek z bielą, co potwierdzają etymologie tych kolorów w wielu językach indoeuropejskich (Tokarski, 2004, s. 71). Jest to więc biały z metalicznym połyskiem, przywołujący prototypy księżyca i gwiazd. W materiale onimicznym znaczenia te potwierdzają połączenia srebrnego z wodą i wierzchołkami gór, co oznacza zapewne obiekty jasne i błyszczące, np. rzeka Srebrna wcześniej nosiła nazwę Moyser Bach 1845, ale też Helle Bach 'jasny potok' (p. dopł. Wilczycy, Bóbr, Odra, NGŚ XIII 12).

Niewiele jest nazw niederywowanych typu Silber 1679, pol. Żelisław, n. przejściowa Srebrnik, wś, gm. Małomice, lubus., NGŚ XVI 183; większość nazw to derywaty złożone.

Najczęściej człon związany ze srebrem i kolorem srebrnym wykorzystywany jest w nazwach obiektów wodnych: Silber Fl. 1717, pol. Srebrna Woda, potok,

${ }^{7}$ Pośrednio z wyrazem złoto i kolorem złotym związane są nazwy służebne, np. Złotniki : złotnicy 'wytwórcy ozdób ze złota i drogich kamieni' (Zlotnici 1260, pol. Złotniki, wś, gm. Prószków, opol., NGŚ XVI 157) czy nazwy zawierające człony pochodne, np. Goldgrubenhübel 'góra przy kopalni złota' (Goldgrubenhübel przed 1945, pol. Złote Jamy, góra, G. Izerskie, Sudety Zach., NGŚ XVI 156). 
p. dopł. Walimki, dorz. Bystrzycy, Odra, NGŚ XIII 12, ESHP; Silber Bach 1993, pol. Srebrnik, też Srebrny Potok, potok, p. dopł. Złotnej, Bóbr, Odra, NGŚ XIII 13; Silber Quelle przed 1945, pol. Srebrne Źródto, też Orle Źródto, źródło pod twierdzą srebrnogórską, d. pow. ząb., dlnśl., NGŚ XIII 12; Silberquelle przed 1945, pol. Srebrne Źródło, źródło u podnóża Wysokiego Kamienia, G. Stołowe, Sudety Środ., NGŚ XIII 12; i górskie: Silber Berg przed 1945, pol. Srebrna, wzniesienie w Grzbiecie Małym, G. Kaczawskie, Sudety Zach., NGŚ XIII 12; Silberberg 1331, pol. Srebrna Góra, wś, gm. Stoszowice, dlnśl., NGŚ XIII 12; Silberkamm przed 1945: der Kamm 'grzebień, grzbiet', pol. Srebrny Upłaz, też Srebrny Grzebień, Srebrna Grań, Srebrna Orań, zbocze Smogorni, Karkonosze, Sudety Zach., NGŚ XIII 13; Silberstein przed 1945, pol. Trzy Korony, wzniesienie, Rudawy Janowickie, Sudety Zach., NGŚ XIV, 105; Silber Lehne przed 1945: niem. 'srebrne zbocze', pol. Radoń, też Złota Góra, góra, Pog. Wałbrzyskie, Sudety Środ., NGŚ XI 98.

Istnieją też nazwy mniejszych obiektów zawierające w nazwie przymiotnik srebrny, notowane przez przewodniki i słowniki geograficzne, niepoświadczone w języku niemieckim, np.: Srebrne Turniczki 1993, urwiska skalne pod krawędzią Kotła Małego Stawu, NGŚ XIII 12; Srebrny Widok 1993, łąka na stoku Rudzianek w Zachełmiu, gm. Podgórzyn, dlnśl., NGŚ XIII 13; Silber Wiese przed 1945, pol. Srebrna Łąka, łąka w Lasockim Grzbiecie, Karkonosze, Sudety Zach., NGŚ XIII 12.

Sporadycznie nazwy zachowują starą formę przymiotnika strzebny, np. Strebrincop ok. 1300: srebrny kop 'srebrna góra', pol. Strzybnik, wś, gm. Rudnik, śl., NGŚ XIII 102; lub decyzją KUNM Strzybnik, też Strzybne Skały 1993, góra, G. Złote, Sudety Wsch., NGŚ XIII 102.

\subsection{Niem. rot / pol. czerwony / rudy / rdzawy}

W języku niemieckim przymiotnik rot oznacza 'czerwony', ale też 'rudy, ryży' (raczej o człowieku i jego włosach). Słownik Grimmów podaje, że przymiotnik roth dawniej mógł też określać kolor złoty, następnie zbliżył się w stronę brązowego, szczególnie żółtawobrązowego i czerwonobrązowego oraz obejmował takie kolory, jak szkarłatny, krwisty, miedziany, karminowy, jaskrawoczerwony, różowoczerwony, jasnoczerwony (DWB).

Wiele nazw zawierających niemiecki element rot zostało przetłumaczonych (naturalnie lub sztucznie) na polskie czerwony. Są to nazwy związane z wodą: Rotes Wasser 1915, pol. Czerwienica, rzeka, p. dopł. Miedzianki, Nysa Łużycka, Odra, NGŚ II 68, ESHP; Rothwasser 1927, pol. Czerwona Woda, wś, gm. Węgliniec, dlnśl., NGŚ II 69; rothe fl. [oss] 1736, pol. Czerwony Potok, potok, 1. dopł. Kwisy, Bóbr, Odra, NGŚ II 71, ESHP; Rothflus 1665, pol. Czerwony Strumień, nieistniejąca wieś, gm. Międzylesie, dlnśl., NGŚ II 71; Rote Lache przed 1945, pol. Czerwone, cz. lasu, Koniowo, gm. Trzebnica, dlnśl., NGŚ II 70; nazwy górskie: Roterberg 
przed 1945, pol. Czerwieniec, góra, Pogórze Izerskie, Sudety Zach., NGŚ XII 68; Rotheberg, pol. Czerwoniak, góra, Kotlina Kłodzka, Sudety Środ., NGŚ II 70; Rote Höhe przed 1945, pol. Czerwota, góra, Kotlina i Brama Krzeszowska, Sudety Środ., NGŚ II 71; Rothe Grund 1786, pol. Czerwoniak, też Czerwona Dolina, cz. wsi Sosnówka, gm. Podgórzyn, dlnśl., NGŚ II 70; także nieliczne nazwy kulturowe: Rothaus 1845, pol. Czerwony Dwór, przys. do wsi Brzezina, gm. Brzeg, opol., NGŚ II 70; Czerwony dwór 1879, też Rothe H. [of], przys. wsi-gm. Jaworze, śl., NGŚ II, 70; Rothneudorff 1743, pol. Czerwieniec, wś, gm. Łagiewniki, dlnśl., NGŚ XII 68; Rothkirch, łac. Ruffa ecclessia ok. 1300, pol. Czerwony Kościót, daw. też Studzienica, wieś, gm. Krotoszyce, dlnśl., NGŚ XII 70.

Nazwy polskie niemające odpowiedników niemieckich również wykorzystują przymiotnik czerwony, np. Czerwona Grobla 1845, pustkowie we wsi Płużniczka, gm. Toszek, śl., NGŚ II 69; Czerwona Górka przed 1945, wzgórze, daw. pow. krap., NGŚ II 69; Czerwona Góra przed 1945, wzgórze, daw. pow. lwów., NGŚ II, 69.

W nazwach polskich na Śląsku zachowała się też gwarowa forma czerwiony, np.: Czerwiona górka ok. 1934, n. ter. we wsi Rozbark, obecnie cz. mta Bytom, śl., NGŚ II, 68; villa Czerwonko 1679, Czervienka 1687/1688, cz. mta Pyskowice, śl., NGŚ II, 68-69; Czerwencka 1743, Czerwonka 1784, dziś Czerwionka-Leszczyny, mto-gm., śl, NGŚ II 68-69.

W wielu powojennych nazwach geograficznych KUNM thumaczyła niemieckie rot jako rudy: Roter Hübel przed 1945: niem. 'rude zbocze', dziś Rudawka, góra, daw. pow. jel., NGŚ XII 16; Rote Höhe przed 1945: niem. 'rude wzgórze', dziś Rudawka, góra, Pogórze Bolkowickie, Sudety Wsch., NGŚ XII 16; Rote Berg, dziś Rudna, wzgórze, wś Rudna, dlnśl., NGŚ XII 17; Rothe Gr.(aben) 1889, dziś Rudnica, rzeka, p. dopł. Czerńca, dorz. Cichej Wody, Odra, NGŚ XII 19, ESHP; Rothe Lehne przed 1945: niem. 'czerwone zbocze', dziś Rudnica, daw. pow. jel., NGŚ XII 19; Roter Sandhaufen przed 1945: niem. 'kupa rudego piasku', dziś Rudnik, n. ter., daw. pow. bol., NGŚ XII 19; Roter Saum 1845: niem. 'rudy brzeg, skraj’, dziś Rudy Krajek, kolonia Nowej Świdnicy, gm. Olszyna, dlnśl., NGŚ XII 21; Rothe Sümpfe przed 1945: niem. 'rude bagna', dziś Rudawiec, polana na północnym stoku góry, G. Bialskie, Sudety Wsch., NGŚ XII 16; Rothe Lache przed 1945: 'ruda łacha, kałuża', dziś Ruda Łacha, mokradło, daw. pow. woł., NGŚ XII 14; Rotes Floss przed 1945, pol. Rudzik, strumyk, dopł. Maliny, dorz. Jedlicy, Łomnica, Bóbr, NGŚ XII 24.

Bardzo trudno stwierdzić, które z nazw polskich zawierają element rudy w znaczeniu przymiotnikowym 'czerwony, rdzawy', por. rudy i rudawy 'rdzawy, ryży, czerwonobrązowy' (SStp VIII 43-44), 'czerwonobrązowy, rdzawy' (SpXVI, XXXVII 127), 'śniady, brudnoczerwony, jak ruda' (SWil II 1423), 'śniadobrudnoczerwony, jak ruda; żółtoczerwony'. Zapewne określenie koloru znajdziemy w nazwach z elementem rudny 'czerwony, rdzawy', por. Rudna 1347, wś-gm., 
dlnśl., NGŚ XII 17; Rudnak (rudinok) ok. 1934, ogólnopolski Rudniak, n. ter., wś Brynica, gm. Łubniany, opol., NGŚ XII 18; Rudno 1228-43, dziś Rudnica, wś, gm. Stoszowice, dlnśl., NGŚ XII 18-19.

Polski rdzeń rud-jest polisemantyczny. Może pochodzić również od rzeczownika ruda, który oznaczał w staropolszczyźnie ‘surowiec mineralny, z którego wytapia się jakiś metal' oraz 'prymitywny zakład hutniczo-metalurgiczny' (SStp VIII 43), por. liczne derywaty: rudny 'mający związek z rudą', rudnik 'wydobywający rudę, pracujący w kopalni' lub 'wytapiacz żelaza z rudy' (SStp VIII 44; SW V 765), rudnia ‘kopalnia rudy', rudnik 'górnik' (SW V 764). Na minerały może wskazywać nazwa Ruda fluvio 1258, dziś Ruda, rzeka, p. dopł. Odry, NGŚ XII 13, o zakładzie metalurgicznym — nazwa Ruda ok. 1300, dziś Ruda Śląska, mto, śl., NGŚ XII 15, wiąże się bowiem z istnieniem w tym miejscu kuźnicy (najpierw ołowiu, potem żelaza). Jednym z rodzajów rud są rudy darniowe, występujące na mokradłach i łąkach, stąd znaczenie rzeczownika ruda 'torf miałki, przesiąknięty wodą; błoto; bagnisko' (SW V 763), por. derywaty: rudzina 'małe bagno', rudawa 'odmiana bagna, zwana tak zapewne od koloru rudego' i 'góra obfitująca w rudę' (SW V 764), np. Rudowke 1731, dziś Rudawka, cz. Międzyrzecza Górnego, gm. Jasienica, śl., NGŚ XII 16; Die Rudofke Lache 1786/87: 'kałuża Rudawka', dziś Rudawka, n. ter., Gosławice, gm. Miękinia, dlnśl., NGŚ XII 16.

W odcieniach koloru czerwonego pojawia się jeszcze $r d z a w y$, znany w staropolszczyźnie jako 'mający kolor rdzy' (SStp IX, 445), 'czerwonobrunatny' (SpXVI, XXXV 176), ‘rudawy, rdzy pełen' (SL V 33-34) i poświadczony m.in. w nazwach wodnych: Rdzawka 1951, rzeka, 1. dopł. Kłodnicy, dorz Odry, NGŚ XI 118; Rotwasser fl. [oss] 1660, pol. Rdzawa (też Czerwony Potok), potok, dorz. Bystrzycy, Odra, NGŚ XI 118, ESHP.

Kolor purpurowy 'krwistoczerwony' (SWil II 1330), 'koloru purpury, czerwonokrwisty, szkarłatny' (SW V 436); 'ciemnoczerwony z odcieniem fioletowym' (SJPDor VII 735) pojawia się tylko w nazwie polskiej Purpurowe Jeziorko, też Czerwone Jeziorko, która pierwotnie brzmiała Schwefelkies Grube 1998: niem. 'kopalnia pirytu', wyrobisko po kopalni łupków pirytowych, koło Wieściszowic, gm. Marciszów, dlnśl., NGŚ XI $72^{8}$.

\footnotetext{
${ }^{8}$ Purpurowe Jeziorko jest elementem kompleksu Kolorowe Jeziorka, związanego z istnieniem w tym miejscu kopalni pirytu. Nazwy kolorów zwracają uwagę na skład chemiczny ścian i wyrobiska: Purpurowe Jeziorko swoją barwę zawdzięcza roztworowi kwasu siarkowego, Żólte Jeziorko wypełnia woda o żółtawym zabarwieniu, Niebieskie Jeziorko, zwane także Lazurowym, Szmaragdowym lub Błękitnym, swój kolor ma dzięki związkom miedzi, a Zielone Jeziorko (nazwane tak ze względu na odbijające się w nim drzewa) podczas powodzi nazywano też Czarnym Jeziorkiem; por. https:// kolorowejeziorka.pl/historia, https://pl.wikipedia.org/wiki/Kolorowe_jeziorka (dostęp: 19.02.2021).
} 
Zupełnie sporadycznie KUNM zdecydowała się przetłumaczyć niemieckie rot na różowy: Rothe Hübel przed 1945, pol. Różanka, góra, Wzgórza Lewińskie, Góry Stołowe, NGŚ XII 12. Nazwy polskie kojarzące się z tym kolorem nawiązują prawie zawsze do niemieckiego rzeczownika Rose 'róża'.

\subsection{Niem. kupfer / miedziany}

Niemiecki człon kupfer może oznaczać rzeczownik Kupfer 'czerwonawy metal nieszlachetny', jak i przymiotnikowy kupfer-, występujący w połączeniach typu kupfergeld 'miedziane monety' (sam przymiotnik kupfern w nazwach nie występuje). W słowniku Grimmów jest też mowa o kolorze miedzianym, np. twarzy (DWB).

W języku polskim przymiotnik miedziany używany jest w znaczeniu 'zrobiony z miedzi, związany z miedzią, podobny do miedzi' (SStp IV 219; SWil I 655). Interesujące nas znaczenia podają słowniki od XVI wieku: 'koloru miedzi, rudy' (SpXVI, XIII 565); miedziany i miedziowy to 'przymiotnik od miedź (zawierający miedź lub koloru miedzi)', por. też miedzianka górn. 'ruda miedziana' (SW II 952-953); miedziany 'zrobiony z miedzi', ale też 'koloru miedzi; o odcieniu pomarańczowo-czerwonym, rdzawym' (SJPDor IV 634).

Nazwy z niemieckim elementem nawiązującym do miedzi i koloru miedzianego to: Kupferhübel 1941: niem. 'miedziowe zbocze', pol. Miedziak, os. do Nowej Rudy, dlnśl., NGŚ VII, 135; Kupferberg 1784: niem. 'miedziana góra', pol. Miedziana, też Miedziana Góra, wś, gm. Tarnów Opolski, opol., NGŚ VII, 135 (to nazwa przeniesiona, gdyż nie było tu miedzi); Cupra 1346, Koppher, Kopphir 1404: niem. Kopfer 'miedź', łac. cuprum, wś, gm. Sulików, dlnśl., NGŚ VII, 135; Kupferberger Steine przed 1945, pol. Miedziane Skaty, skały, Rudawy Janowickie, Sudety Zach., NGŚ VII, 136; Kupfferberg 1605, pol. Miedzianka, wś, gm. Janowce Wielkie, dlnśl., NGŚ VII, 136; das flyss die Kopper 1503, pol. Miedzianka, rzeka, p. dopł. Nysy Łużyckiej, Odra, NGŚ VII, 136, ESHP.

\subsection{Pol. szary/siwy/szady/ niem. grau}

Odcienie szarości są charakterystyczne przede wszystkim dla nazw polskich. Określenie szary jest w tej grupie najbardziej neutralne, w staropolszczyźnie ‘ciemnopopielaty, może też niebieski' (SStp VIII 535), ale później już najczęściej 'mający kolor mieszany z czarnego i białego' (SWil II 1619), 'ciemnosiwy, popielaty' (SW VI 571), ‘białoszary, jasnoszary, jasnopopielaty' (SJPDor VIII 245), też 'ciemny, mroczny' (SJPDor VIII 1029). Kolor ten jest podstawą nazw: Szarÿ dol ok. 1934, n. ter., wś Smolnica, gm. Sośnicowice, śl., NGŚ XIII 129; 
Scharzinafeld, Zarzinafeld ok. 1934, pol. Szarzyna, n. ter., wś Grodzisko, gm. Strzelce Opolskie, opol., NGŚ XIII 130.

W języku staropolskim siwy w znaczeniu ‘białoszary’ był raczej zastrzeżony dla maści konia, ogólnie zaś oznaczał 'niebieskofioletowy, może też ciemnoniebieski' (SStp VIII 213), później częściej ‘będący koloru między białym a czarnym' (SWil II 1586; SL V 273), 'odznaczający się kolorem białym, wpadającym nieco w czarny', por. siwe wody, siwe skaty, 'białoszary, jasnoszary, jasnopopielaty' (SJPDor VIII 245), chociaż „Słownik warszawski” notuje też 'niebieski, modry, błękitny' (SW VI 124). Na Śląsku istnieją polskie nazwy pochodzące od tego przymiotnika, np.: Siwka 1951, rzeka, 1. dopł. Prószkowskiego Potoku dorz. Odry, NGŚ XII 98, ESHP; Schiwki ok. 1934, dziś Siwki, n. ter. w Ściborzycach Wielkich, gm. Kietrz, opol., NGŚ XII 98. Niemieckie Graue Allee ok. 1954: niem. 'szara aleja' KUNM przetłumaczyła jako Siwa Aleja, droga w daw. pow. niemodl., NGŚ XII 97.

Ciekawym reliktem przeszłości jest określenie koloru szady, pochodzące od stp. szady 'siwy, pokryty siwizną', już w staropolszczyźnie występujące prawdopodobnie w nazwach terenowych, por. szady kierz (SStp VIII 529)9. Przymiotnik ten nie jest znany współcześnie, zaniknął prawdopodobnie w ciągu XVII wieku (Zaręba, 1954, s. 14), w „Słowniku wileńskim” i u Lindego jest już tylko przymiotnik szadawy ‘popielaty' (SL V 544; SWil II 1612). W kartotece „Słownika gwar śląskich" notuje się apelatyw szady w znaczeniu 'siwy, szroniasty' (SGŚ kart.), które zapisało się także w nazwach terenowych i wodnych: Schade-Eugi ok. 1934, pol. Szade Ługi, n. ter., wś Dąbrówka, gm. Wielowieś, śl., NGŚ XIII 126; Szadok 1772, cz. Katowic, śl., NGŚ XIII 126; Szadzica 1951, rzeka, 1. dopł. Średzkiej Wody, NGŚ XIII 127.

\subsection{Niem. blau/pol. modry/siny}

Niemiecki przymiotnik blau oznacza 'niebieski', związany z kolorem nieba i skał, zawierający w sobie gamę kolorów od jasnoniebieskiego, błękitnego, po ciemnoniebieski, kobaltowy i jasnofioletowy (DWB). Element blau w nazwach niemieckich realizowany jest jako polskie modry i siny. Takie decyzje KUNM potwierdzają znaczenia tych leksemów w polszczyźnie.

Siny od doby staropolskiej miał znaczenie 'niebieskofioletowy, może też ciemnoniebieski, niebieski wpadający w czarny' (SStp VIII 205), 'ciemniejszy od błękitnego' (SWil II 1484), 'niebieski, modry' (SW VI 116), 'niebieskofioletowy, czasem z odcieniem szarym, reg. ciemnoniebieski', może miał też związek

${ }^{9}$ Przykłady wykluczają raczej znaczenie 'kosmaty, najeżony, rozczochrany' (SW VI 553), tak jak w języku kaszubskim ‘rozłożysty, rozgałęziony’ (o lesie) 
z określeniem siny kamień 'siarczan miedzi' (SJPDor VIII 233). Poświadczone nazwy polskie pochodzą od niemieckiego blau: Blaue Steine 1989, pol. Sine Skatki, góra, Wysoki Grzbiet, G. Izerskie, Sudety Zach., NGŚ XII 94; Blauer Berg 1928, pol. Siniak, góra, Grupa Śnieżnika, Sudety Wsch., NGŚ XII 94.

Modry w staropolszczyźnie oznaczał 'niebieski lub fiołkowy' (SStp IV 323), w XVI wieku 'niebieski o dużej intensywności: nasycony niebieski, ciemnoniebieski, fioletowy' (SpXVI 568), później już tylko 'błękitny, niebieski' (SWil I 675), 'bławatny, szafirowy' (SW II 1028); 'niebieski o dużej intensywności, ciemnoniebieski, ciemnobłękitny' (SJPDor V 799). Element ten zachował się tylko w jednej nazwie śląskiej: Blaustein przed 1945: niem. blau 'niebieski', der Stein 'kamień', pol. Modrak, góra, Wzgórza Radomickie, Pog. Izerskie, Sudety Zach., NGŚ VIII 51.

Interesujące jest to, że brak w nazewnictwie polskim określeń błękitny czy niebieski (wyjątek stanowi Niebieskie Jeziorko ${ }^{10}$, zwane także Lazurowym). Należy to thumaczyć tym, że sam leksem niebieski w znaczeniu 'koloru nieba' notowany jest w „Słowniku polszczyzny XVI wieku” z niewielkimi przykładami użycia, a u Lindego dopiero z końca XVII wieku (por. Zaręba, 1954, s. 41).

\subsection{Inne, rzadko występujące kolory}

Leksem żólty znany był w staropolszczyźnie i oznaczał 'mający barwę siarki, słonecznika czy złota' (SStp XI 598) i to on przede wszystkim określał kolor złota w gwarach (Zaręba, 1954, s. 33). Podobnie jak złoty, symbolizował życie i płodność oraz związany był z jasnością, ogniem i Bogiem (Libera, 1987, s. 126). W toponimii śląskiej (podobnie jak w polskiej) występuje niezwykle rzadko, por. Gelblach 1929, pol. Żólta Woda, Żótty Potok, potok, p. dopł. Nysy Łużyckiej, dorz. Odry, NGŚ XVI 190, ESHP.

Niemieckie braun 'brązowy, brunatny' nie ma dokładnego thumaczenia w nazwach polskich. Niemiecka nazwa Brauner Berg to pol. Rudzik (góra, Sokole Góry, Rudawy Janowickie, Sudety Zach., NGŚ XII 24). Szukając odpowiedzi na pytanie, dlaczego elementy brunatny i brazowy tak rzadko pojawiają się w nazwach geograficznych, należy zwrócić uwagę na to, że koloru brązowego rzadko używa się do nazwania koloru gleby, a sam wyraz notowany jest dopiero w XIX wieku w „Słowniku wileńskim” (SWil I 108). Poza tym brunatny w gwarach oznacza także 'purpurowy i fioletowy' i 'ciemny' (Zaręba, 1954, s. 26), a istniejące połączenia gwarowe mają wyraziste ograniczenia łączliwości (np. gniada sierść, śniada cera, por. Różycka, 2001, s. 80).

\footnotetext{
${ }^{10}$ Por. https://kolorowejeziorka.pl/historia (dostęp: 19.02.2021).
} 


\section{WNIOSKI}

Analiza wybranej grupy nazw pokazała, jak wiele problemów wiąże się z omawianymi nazwami, jak różne są sposoby adaptacji tych nazw i jak trudne jest potwierdzenie konkretnych znaczeń. Współistnienie na opisywanym terenie nazw polskich i niemieckich stanowi, z jednej strony, bogactwo językowe i kulturowe, ale $\mathrm{z}$ drugiej strony powoduje wiele problemów interpretacyjnych.

Wiele powojennych nazw polskich z członami określającymi kolor nie nawiązuje w żaden sposób do wcześniejszych niemieckich nazw przedwojennych. Zdarza się jednak i tak, że nawiązania Komisji Ustalania Nazw Miejscowych mogą wskazywać na pewne konotacje i asocjacje repolonizowanych nazw, np. Złoty Stok pierwotnie nosił nazwę Reichenstein 'bogaty gród' (Richinstein 1293, NGŚ XVI 160), co pokazuje związek znaczeniowy wyrazu złoty i bogaty. „Słownik wileński” jako drugie znaczenie leksemu złoty podaje przecież 'cenny, kosztowny, uszczęśliwiający, szczęśliwy, wyborny, drogi' (SWil II 2225).

Czasem zmiany nazw zdają się przeczyć temu, że konkretna nazwa koloru miała znaczenie, np.: niemiecka nazwa Farbenstein przed 1945: niem. 'kolorowy' to pol. Czerwone Skałki (też Kolorowy Kamień, skałki, daw. pow. jel., NGŚ II 70); Schwarzes Floss to pol. Czerwony Potok (potok, daw. dopł. Kamienicy, dorz. Bobru, Odra, NGŚ II 71), a Gold Br.[unnen] 1938 to pol. Srebrnik, też Śnieżna Woda (źródło w Masywie Raduni, NGŚ XIII 13, ESHP).

W większości jednak nazwy powojenne są dokładnymi tłumaczeniami nazw niemieckich lub znaczeniowo nawiązują do nich. Jest to dowód na to, że nazwy kolorów występujące w śląskich nazwach geograficznych są istotnymi określeniami właściwości nazywanych obiektów. Prócz odniesień do realnych znaczeń, obrazu naturalnych cech krajobrazu wraz z minerałami, kruszcami i glebami nazwy te są nośnikami znaczeń przenośnych i konotacyjnych.

\section{WYKAZ SKRÓTÓW}

$$
\begin{aligned}
& \text { bol. — bolesławiecki } \\
& \text { cz. - część } \\
& \text { dopł. - dopływ } \\
& \text { daw. - dawny } \\
& \text { dorz. — dorzecze } \\
& \text { dlnśl. — dolnośląskie } \\
& \text { G. - Góry } \\
& \text { gm. — gmina } \\
& \text { jel. - jeleniogórski } \\
& \text { kart. - kartoteka } \\
& \text { krap. - krapkowicki } \\
& \text { 1. — lewy }
\end{aligned}
$$




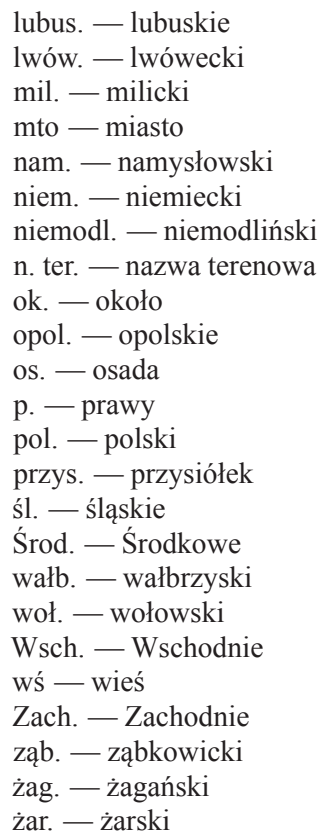

\section{LITERATURA}

Czachorowska, M. i Stypa, H. (2010). Porównania prototypowe barw w językach polskim i niemieckim [Prototype comparisons of colours in the Polish and German languages]. Linguistica Bidgostiana, 7, 7-58.

DWB = Deutsches Wörterbuch von Jacob Grimm und Wilhelm Grimm (1852-1954). Digitalisierte Fassung im Wörterbuchnetz des Trier Center for Digital Humanities, Version 01/21. https:// www.woerterbuchnetz.de/DWB (dostęp: 22.06.2021).

Duma, J. (2003). Nazwy rzek polskich ze słowiańskim przymiotnikowym określeniem barwy wody [Names of Polish rivers with the Slavic adjective term for the colour of water]. W: M. Biolik (red.), Metodologia badań onomastycznych [Onomastic Research Methodology] (s. 385-409). Olsztyn: Ośrodek Badań Naukowych im. W. Kętrzyńskiego w Olsztynie.

$\mathrm{ESHP}=$ Elektroniczny stownik hydronimów Polski [Electronic Dictionary of Hydronyms of Poland] (b.d.). Instytut Języka Polskiego PAN. https://eshp.ijp.pan.pl (dostęp: 22.06.2021).

Gaponenko, I. (2019). The colour names in Belarusian, Russian and Polish toponymy: frequency ways of implementation of semantics, ethnic meaningful characteristics. Annales Universitatis Mariae Curie-Sktodowska, Sectio FF, 37, 41-53.

Gonigroszek, D. (2008). Językowy obraz świata barw i kolorów jako przykład kulturowych różnic w językach [The linguistic image of the world of colours as an example of cultural differences in languages]. Językoznawstwo, 1(2), 91-99.

Grodzicki, A. (2002). Osady złotonośne okolic Głuchołaz w świetle badań geologicznych [Goldbearing settlements in the Głuchołazy area in the light of geological research]. W: P. Chrobak, M. Dąbkowska i P. Szymkowicz (red.), Europejskie dziedzictwo górnictwa złota na terenie 
Gluchołaz i Zlatych Hor [The European Gold Mining Heritage in Głuchołazy and Zlate Hory] (s. 50-56). Głuchołazy: „Aneks”.

Jakus-Borkowa, E. (1989). Przymiotniki właściwościowe w hydronimii polskiej [Property adjectives in Polish hydronymy]. W: K. Rymut (red.), Hydronimia stowiańska. Materiaty z IX Konferencji Komisji Onomastyki Stowiańskiej przy Międzynarodowym Komitecie Slawistów. Mogilany, 16.-18.09.86 [Slavic Hydronymy. Materials from the IX Conference of the Slavic Onomastics Commission at the International Committee of Slavists. Mogilany, September 16-18, 1986] (s. 141-149). Wrocław-Warszawa-Kraków: Zakład Narodowy im. Ossolińskich.

Jurek, K. (2011). Znaczenie symboliczne i funkcje koloru w kulturze [The symbolic meaning and functions of colour in culture]. Kultura - Media - Teologia, 4, 68-80.

Kolorowe Jeziorka [Colourful Lakes] (b.d.). https://pl.wikipedia.org/wiki/Kolorowe_jeziorka (dostęp: 19.02.2021).

Kolorowe Jeziorka w Rudawach Janowickich [Colourful Lakes in the Rudawy Janowickie] (b.d.). Historia. https://kolorowejeziorka.pl/historia (dostęp: 19.02.2021).

Lech-Kirstein, D. (2021). Konotacje nazw barw w toponimii i hydronimii śląskiej (czarny, biaty, zielony) [Connotations of colour names in Silesian toponymy and hydronymy (black, white, green)]. Prace Językoznawcze, 23(2), 91-103.

Libera, Z. (1987). Semiotyka barw w polskiej kulturze ludowej [Colour semiotics in Polish folk culture]. Etnografia Polska, 31(1), 115-138.

Madeja, A. (2010). Skąd pochodzą polskie nazwy kolorów [What is the origin of Polish names of colours]. Postscriptum Polonistyczne, 2(6), 197-217.

Mikoś, T. (2002). XVI-wieczne sztolnie odwadniające na Śląsku [16 $6^{\text {th }}$ century drain drifts in Silesia]. W: P. Chrobak, M. Dąbkowska i P. Szymkowicz (red.), Europejskie dziedzictwo górnictwa złota na terenie Gluchołaz i Zlatych Hor [The European Gold Mining Heritage in Głuchołazy and Zlate Hory] (s. 81-93). Gluchołazy: „Aneks”.

Myszka, A. (2006). Toponimia powiatu strzyżowskiego [Toponymy of the Strzyżów District]. Rzeszów: Wydawnictwo URz.

NGŚ = Rospond, S. (1970). Słownik etymologiczny nazw geograficznych Ślaska [Etymological Dictionary of the Geographical Names of Silesia] (t. I) Borek, H., Rospond, S. (red.). (19851986); (t. II-III); Borek, H. (red.). (1988) (t. IV). Warszawa-Wrocław: PWN; Sochacka, S. (red.). (1991-2016) (t. V-XVII). Opole: Instytut Śląski.

Różycka, I. (2001). Mikrotoponimy motywowane przez nazwy kolorów w kartotece Stownika nazw terenowych Polski [Microtoponyms motivated by the names of colours in the file of the Dictionary of Polish Field Names]. W: K. Michalewski (red.), Wspótczesna leksyka [Contemporary Lexis], II (s. 76-88). Łódź: Wydawnictwo UŁ.

SGŚ = Wyderka, B. (red.). (2000-2020). Stownik gwar ślaskich [A Dictionary of Silesian Dialects] (t. I-XVII). Opole: Instytut Śląski (i kartoteka).

SJPDor $=$ Doroszewski, W. (red.). (1958-1968). Stownik języka polskiego [Dictionary of the Polish Language] (t. I-X). Warszawa: Wiedza Powszechna.

$\mathrm{SL}=$ Linde, S.B. (1951). Stownik języka polskiego [Dictionary of the Polish Language] (t. I-VI). Warszawa: PIW.

SpXVI = Mayenowa, M.R. i Pepłowski, F. (red.). (1966-1995). Słownik polszczyzny XVI wieku [Dictionary of the Polish Language of the $16^{\text {th }}$ Century] (t. 1-34), Mrowcewicz, K. i Potoniec, P. (red.), t. 35-37; Wilczewska, K., Woronczakowa, L. i in. (t. 27-37). Wrocław: Zakład Narodowy im. Ossolińskich.

SPJS = Sieradzka-Baziur, B. (red.). (b.d.). Stownik pojęciowy języka staropolskiego [A Conceptual Dictionary of the Old Polish Language]. Instytut Języka Polskiego PAN. https://spjs.ijp.pan.pl (dostęp: 22.03.2021).

SStp = Urbańczyk, S. (red.). (1953-2002). Stownik staropolski [The Old Polish Dictionary] (t. I-XI). Wrocław-Warszawa-Kraków: Instytut Języka Polskiego PAN. 
SW = Karłowicz, J., Kryński, A.A. i Niedźwiedzki, W. (red.). (1952-1953). Stownik języka polskiego [Dictionary of the Polish Language] (t. I-VIII). Warszawa: PIW.

SWil = Zdanowicz, A. (red.). (1861). Stownik języka polskiego [Dictionary of the Polish Language] (t. I-II). Wilno: Wydawnictwo M. Orgelbranda.

Tokarski, R. (2004). Semantyka barw we wspótczesnej polszczyźnie [Colour Semantics in the Contemporary Polish Language]. Lublin: Wydawnictwo UMCS.

Wierzbicka, A. (1999). Znaczenie nazw kolorów i uniwersalia widzenia [The meaning of colour names and the universals of vision]. W: J. Bartmiński (red.), Język - umyst - kultura [Language - Mind - Culture] (s. 405-449). Warszawa: PWN.

Zaręba, A. (1954). Nazwy barw w historii i dialektach języka polskiego [Colour Names in the History and Dialects of the Polish Language]. Wrocław: Zakład Narodowy im. Ossolińskich.

\section{SUMMARY}

\section{SILESIAN GEOGRAPHICAL NAMES MOTIVATED BY COLOUR TERMS}

The subject of the paper is Silesian geographical names motivated by colour terms. The analysis comprised Polish and German appellative-derived names of inhabited and uninhabited buildings as well as oronyms and hydronyms. The term colour appearing in the title is broadly understood as every element naming a colour, deriving from a colour term or evoking associations with a colour term. The analytical part contains a description of particular colour terms constituting the basis for proper names, with their meanings, connotations and prototypes. It is followed by a presentation of geographical names in which colour terms are elements of juxtapositions, simple compounds and closed compounds, as well as bases for derived names. Polonised and transitional names were also considered in order to emphasize certain phenomena. Apart from the basic colour referring to Silesia (such as black, green, white, red) the bases for proper names can be non-basic colours, such as golden, silver, copper, ginger as well as more rarely used: purple, azure, grey, greyish.

It can be concluded from the analysis that colour names motivated by colours terms not only present a real colour palette but also preserve the image of surface formation, hydrography and the natural characteristics of the landscape, with the minerals, metals and soils in the area, and they can be carriers of valuation and emotion as well.

Keywords: geographical names, names of hues/colours, Silesia 